SAND85-1921 - UC-66d

Unlimited Release

Printed April 1987

\title{
An Experimental Investigation of Pressure Drop of Aqueous Foam in Laminar Tube Flow
}

B. F. Blackwell, Keri Butler Sobolik

Prepared by

Sandia National Laboratories

Albuquerque, New Mexico 87185 and Livermore, California 94550

for the United States Department of Energy

under Contract DE-AC04-76DP00789

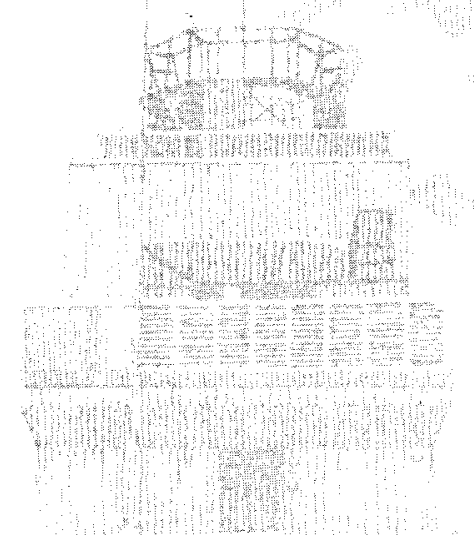




\section{DISCLAIMER}

This report was prepared as an account of work sponsored by an agency of the United States Government. Neither the United States Government nor any agency Thereof, nor any of their employees, makes any warranty, express or implied, or assumes any legal liability or responsibility for the accuracy, completeness, or usefulness of any information, apparatus, product, or process disclosed, or represents that its use would not infringe privately owned rights. Reference herein to any specific commercial product, process, or service by trade name, trademark, manufacturer, or otherwise does not necessarily constitute or imply its endorsement, recommendation, or favoring by the United States Government or any agency thereof. The views and opinions of authors expressed herein do not necessarily state or reflect those of the United States Government or any agency thereof. 


\section{DISCLAIMER}

Portions of this document may be illegible in electronic image products. Images are produced from the best available original document. 
Issued by Sandia National Laboratories, operated for the United States Department of Energy by Sandia Corporation.

NOTICE: This report was prepared as an account of work sponsored by an agency of the United States Government. Neither the United States Government nor any agency thereof, nor any of their employees, nor any of their contractors, subcontractors, or their employees, makes any warranty, express or implied, or assumes any legal liability or responsibility for the accuracy, completeness, or usefulness of any information, apparatus, product, or process disclosed, or represents that its use would not infringe privately owned rights. Reference herein to any specific commercial product, process, or rights. Reference herein to any specific commercial product, process, or
service by trade name, trademark, manufacturer, or otherwise, does not service by trade name, trademark, manufacturer, or otherwise, does not by the United States Government, any agency thereof or any of their contractors or subcontractors. The views and opinions expressed herein do not necessarily state or reflect those of the United States Government, any agency thereof or any of their contractors or subcontractors.

Printed in the United States of America

Available from

National Technical Information Service

U.S. Department of Commerce

5285 Port Royal Road

Springfield, VA 22161

NTIS price codes

Printed copy: A02

Microfiche copy: A0 


\title{
SAND--85-1921 \\ DE87 008401 \\ Distribution \\ $\mathrm{UC}-66 \mathrm{~d}$ \\ An Experimental Investigation of Pressure Drop of Aqueous Foam in Laminar Tube Flow
}

\author{
B. F. Blackwell \\ Aerothermodynamics Division \\ Keri Butler Sobolik \\ Thermal Test and Analysis Division \\ Sandia National Laboratories \\ Albuquerque, NM 87185
}

\begin{abstract}
This report is the first of two detailing pressure-drop and heat-transfer measurements made at the Foam Flow Heat Transfer Loop. The work was motivated by a desire to extend the application of aqueous foam from petroleum drilling to geothermal drilling. Pressure-drop measurements are detailed in this report; a forthcoming report (SAND85-1922) will describe the heat-transfer measurements. The pressure change across a $2.4-\mathrm{m}(8-\mathrm{ft})$ length of the 2.588-cm (1.019-in.) ID test section was measured for liquid volume fractions between 0.05 and 0.35 and average velocities between 0.12 and $0.80 \mathrm{~m} / \mathrm{s}(0.4$ and $2.6 \mathrm{ft} / \mathrm{s})$. The resulting pressure-drop/flow-rate data were correlated to a theoretical model for a Bingham plastic. Simple expressions for the dynamic viscosity and the yield stress as a function of liquid volume fraction were estimated.
\end{abstract}

\section{DISCLAIMER}

This report was prepared as an account of work sponsored by an agency of the United States Government. Neither the United States Government nor any agency thereof, nor any of their employees, makes any warranty, express or implied, or assumes any legal liability or responsibility for the accuracy, completeness, or usefulness of any information, apparatus, product, or process disclosed, or represents that its use would not infringe privately owned rights. Reference herein to any specific commercial product, process, or service by trade name, trademark, manufacturer, or otherwise does not necessarily constitute or imply its endorsement, recommendation, or favoring by the United States Government or any agency thereof. The views and opinions of authors expressed herein do not necessarily state or reflect those of the United States Government or any agency thereof.

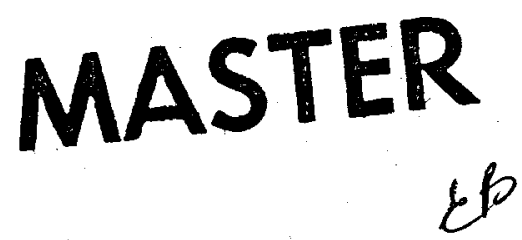

DISTRIBUTIO OF THS DOCUMENT IS UNLIMLEZ 


\section{Acknowledgment}

This work was supported by the U. S. Department of Energy at Sandia National Laboratories under contract DE-AC04-76DP00789. The authors wish to express their appreciation to S. T. Le Tourneau, Division 7521, for his many hours spent conducting the experimental runs and maintaining the experimental apparatus; $V$. Koonce, 5173, for construction of the apparatus; and B. G. Strait, 7537, for the initial programming of the data acquisition system.

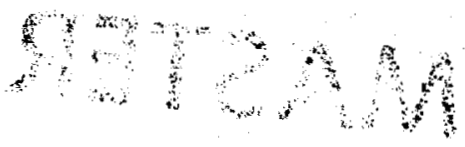




\section{Contents}

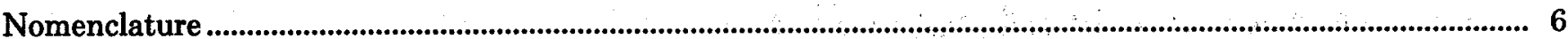

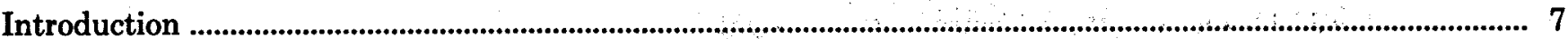

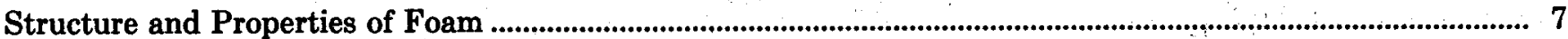

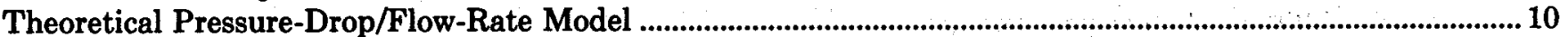

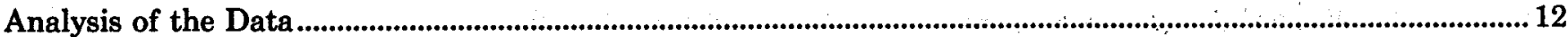

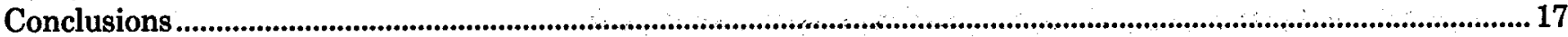

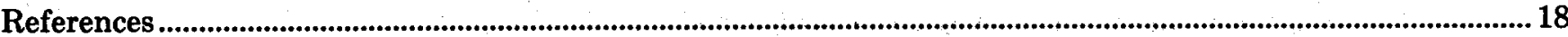

APPENDIX -Description of the Experimental Apparatus .......................................................................................19

\section{Figures}

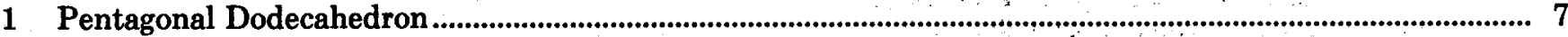

2 Microphotographs of Foam Sample at Different Times After It Was Drawn ................................................ 9

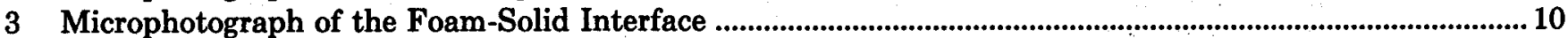

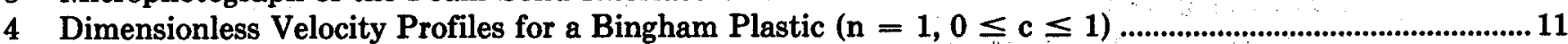

5 Dimensionless Velocity Profiles for a Power-Law Fluid .......................................................................12

6 Dependence of the Friction-Factor/Reynolds-Number Relationship Upon the

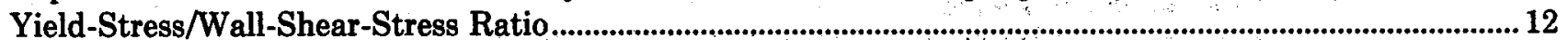

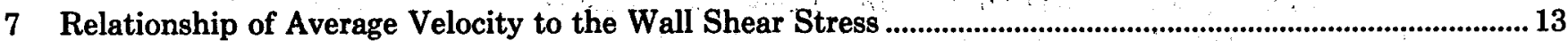

8 Variation of the Bingham Plastic Viscosity With Liquid Volume Fraction.......................................................17

9 Variation of the Bingham Plastic Yield Stress With Liquid Volume Fraction ................................................. 17

\section{Tables}

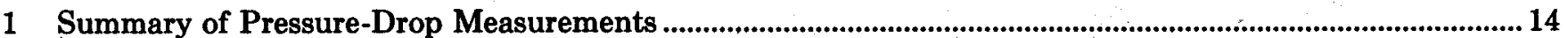

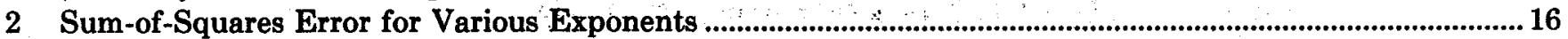




\section{Nomenclature}

B Dimensionless yield stress, Equation (13)

C Yield stress to wall shear stress ratio $=\tau_{\mathrm{y}} / \tau_{\mathrm{w}}$

D Tube diameter

f Friction factor, Equation (13)

g. Acceleration due to gravity

h Vertical distance between pressure measurement ports

L Distance between pressure measurement ports

m Exponent $=1 / \mathrm{n}$

n Exponent, see Equations (4), (6)

NLINA nonlinear parameter estimation program

$\Delta p \quad$ Measured or total pressure change

$\Delta \mathrm{p}_{\mathrm{f}} \quad$ Pressure change due to friction

$r$ Radial position

$\mathbf{r}_{\mathrm{w}}$ Wall or tube radius

$r_{y}$ Radial position at which $\tau=\tau_{y}$

$\mathbf{r}^{+} \quad$ Dimensionsless radial position $=\mathbf{r} / \mathbf{r}_{\mathbf{w}}$

Re Reynolds number $=\rho \pi \mathrm{D} / \eta$

$S$ Sum of squares of differences between data and predictions:

u Local velocity

u Average velocity

$u_{\max }$ Maximum velocity

$\mathbf{u}^{+}$Dimensionless local velocity $=\mathbf{u} / \overline{\mathbf{u}}$

$\delta$ Uncertainty

$\eta$ Dynamic viscosity

$\rho, \rho_{\ell}, \rho_{\mathrm{g}}$ Density of foam, liquid, and gas constituents, respectively

$\tau$ Local shear stress

$\tau_{\mathrm{w}} \quad$ Wall shear stress

$\tau_{\mathrm{y}}$ Yield stress

$\phi$ Liquid volume fraction 


\section{An Experimental Investigation of Pressure Drop of Aqueous Foam in Laminar Tube Flow}

\section{Introduction}

Aqueous foams have many applications that include fire fighting, petroleum drilling, and personnel barriers. This study was motivated by the desire to extend the application of foam for petroleum drilling to geothermal drilling where formation temperatures may exceed $250^{\circ} \mathrm{C}\left(482^{\circ} \mathrm{F}\right)$. Some of the reported advantages of foams as a drilling fluid are:

- Low density produces low bottom hole pressure

- Sand and cuttings fall back very little when circulation stops

- Low loss of circulation into surrounding formation.

To properly size the equipment to deliver foam for a specific application, it is necessary to know the pressure drop as a function of flow rate for various foam consistencies (liquid volume fractions). This report discusses experimental results of pressure drop as a function of flow rate for liquid volume fractions in the range of 0.05 to 0.35 . Based upon an assumed model of a Bingham plastic, both the effective viscosity and yield stress have been estimated from the experimental measurements.

A companion report ${ }^{1}$ details the results of thermal experiments conducted with aqueous foams. These experiments will provide input to a computer model that will be used to ascertain the suitability of using foam in a high-temperature geothermal environment.

\section{Structure and Properties of Foam}

Aqueous foams are two-phase mixtures of a gas (usually nitrogen or air) and a liquid consisting of water plus surfactant. Foam is often characterized by its liquid volume fraction, which is defined as

$\phi=\frac{\text { liquid volume }}{\text { liquid volume }+ \text { gas volume }}$
Many properties of foam, such as density and viscosity, are functions of the liquid volume fraction: by

Foam density is related to liquid volume fraction

$\rho=\phi \rho_{\ell}+(1-\phi) \rho_{\mathrm{g}}$

where $\rho, \rho_{l}$, and $\rho_{\mathrm{g}}$ are the densities of the foam, the liquid component, and the gas component, respectively.

In the liquid-volume-fraction range of interest, foams are described by Bikerman ${ }^{2}$ as agglomerations of gas bubbles separated by thin liquid films, as opposed to gas emulsions in which the thickness of the interstitial liquid layers is approximately the same as the diameter of the bubble. The ideal foam cell is a pentagonal dodecahedron (Figure 1). The data of David and Marsden ${ }^{3}$ indicate that cell size is in the range of 100 to $800 \mu \mathrm{m}(0.004$ to $0.032 \mathrm{in}$.). Cell size is strongly dependent on the details of the foam generator and the generation pressure.

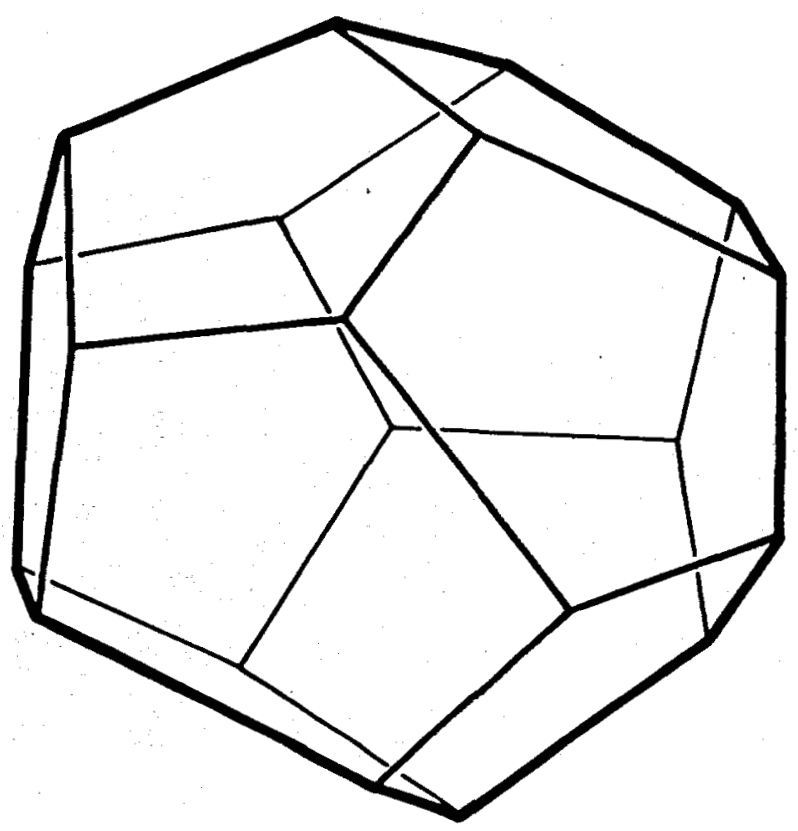

Figure 1. Pentagonal Dodecahedron 
The liquid within the cell interfaces will drain in a gravitational field; hence, the foam has a limited lifetime in a static environment. When a foam sample is placed in a container, the majority of the liquid will eventually collect in the bottom of the container. During this drainage process, the structure of the foam becomes very fragile, almost like a spider web. Figures 2a-c are microphotographs of the time varying structure of a foam sample (shown with a scale with small divisions of $1 / 64$ in. for reference). A foam sample was placed in a container open to the atmosphere. The microscope was focused on the second layer of cells; photographs were taken at times of 3 $\min 28 \mathrm{~s}, 12 \mathrm{~min} 46 \mathrm{~s}$, and $32 \mathrm{~min} 11 \mathrm{~s}$ after the sample was initially drawn. The liquid volume fraction was 0.101 at a test section pressure of 2.58 bar (37.44 psia); after expansion to atmospheric pressure of .84 bar (12.2 psia), the approximate liquid volume fraction was calculated to be 0.035 . As time progresses, small cells coalesce into large cells. If the test section were horizontal, then drainage could be an important factor. In a vertical test section, drainage is still taking place, but since the drainage velocity is small in comparison to the bulk velocity, it was felt that drainage did not have a substantial impact on the test results reported here.

Additional foam drainage studies were conducted by Rand and Kraynik." They found that the time required for a given fraction of the original liquid to drain from the foam increased with decreasing cell size. For their study, cell size was decreased by increasing the pressure at which the foam was generated.

Figure 2 indicates the wide variation in cell size for the foam of this study. Even if it was possible to produce a foam of uniform cell size, there would be a variation in cell structure at a solid/foam interface. Figure 3 is a microphotograph of a solid/foam interface with the foam stationary. This photograph was obtained by filling a container with foam at atmospheric pressure, placing a microscope slide over the top of the container, and focusing the mircoscope on the first layer of cells. The dark region is the wall of the container.

For the present study, air is used as the gas; the surfactant is alpha olefin sulfonate.* The volume ration of surfactant to water is maintained at nominally 0.01 for all tests.

*The surfactant used for all tests in this study is available commercially as Whitconate AOS from Whitco Chemical Company. 


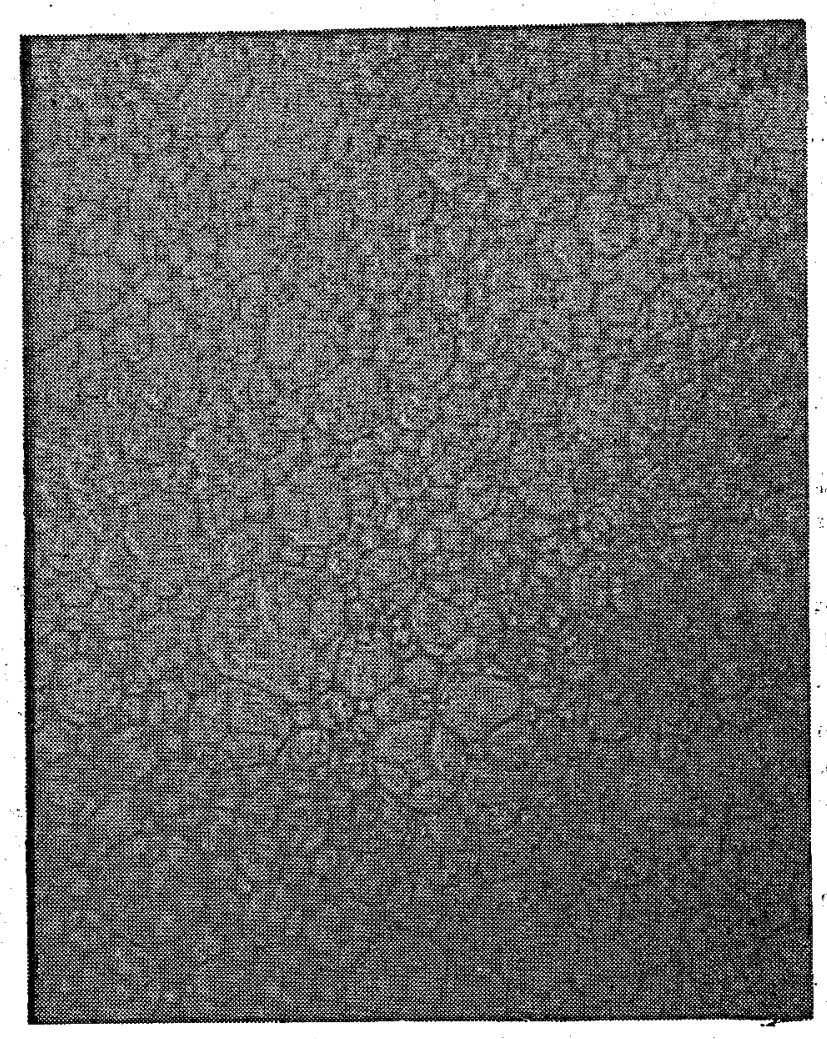

(a) After $3 \min 28 \mathrm{~s}$

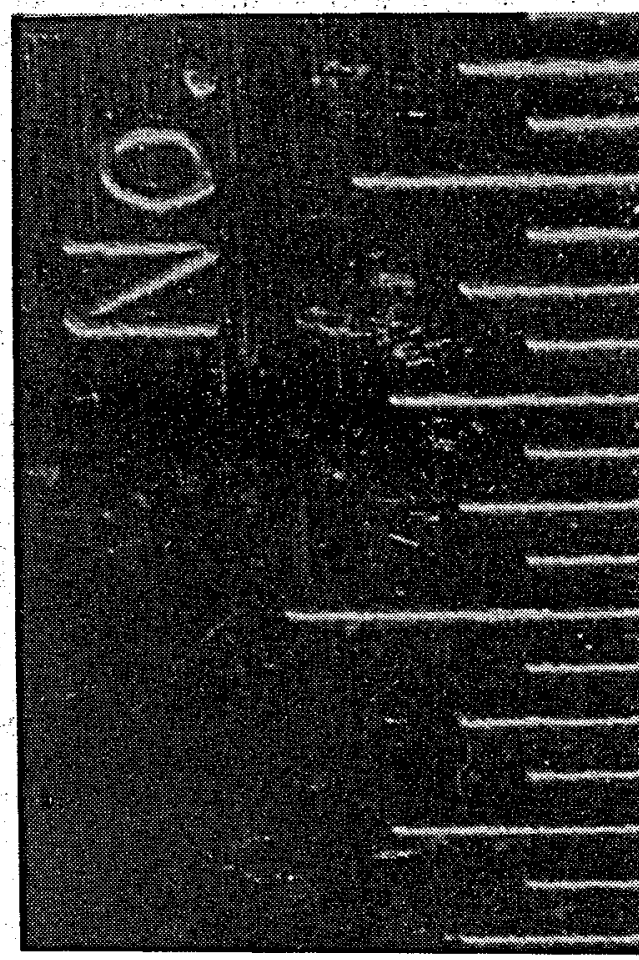

(Scale)

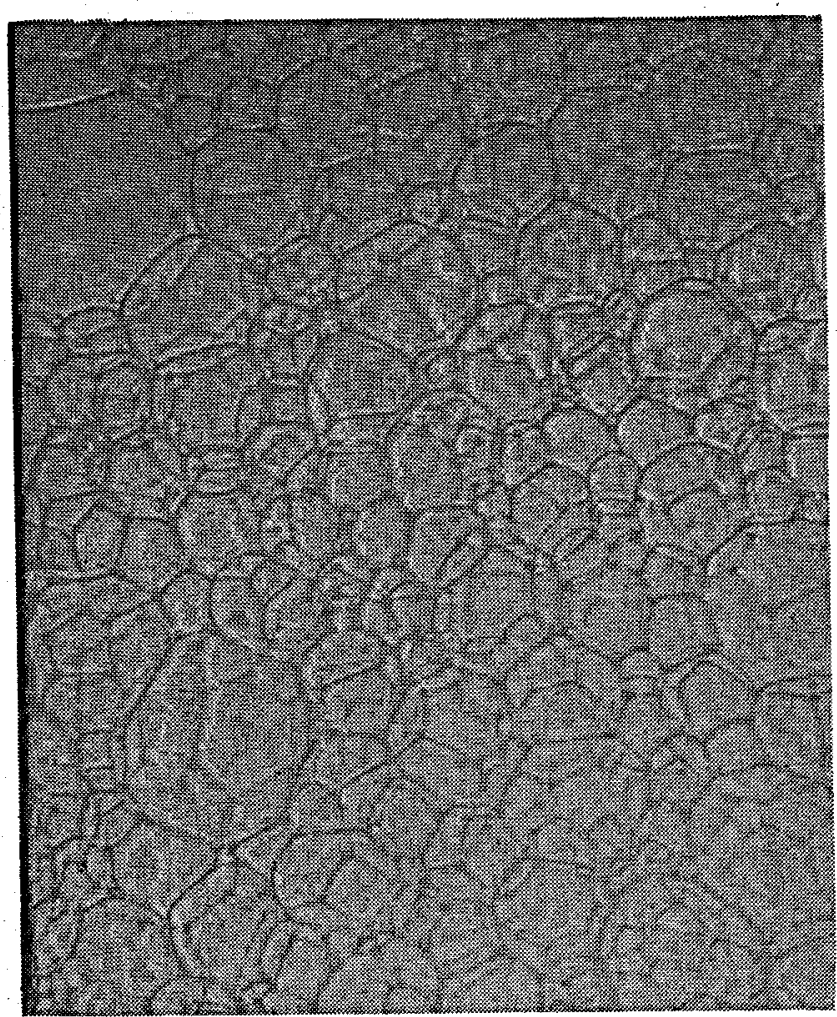

(b) After $12 \min 46 \mathrm{~s}$

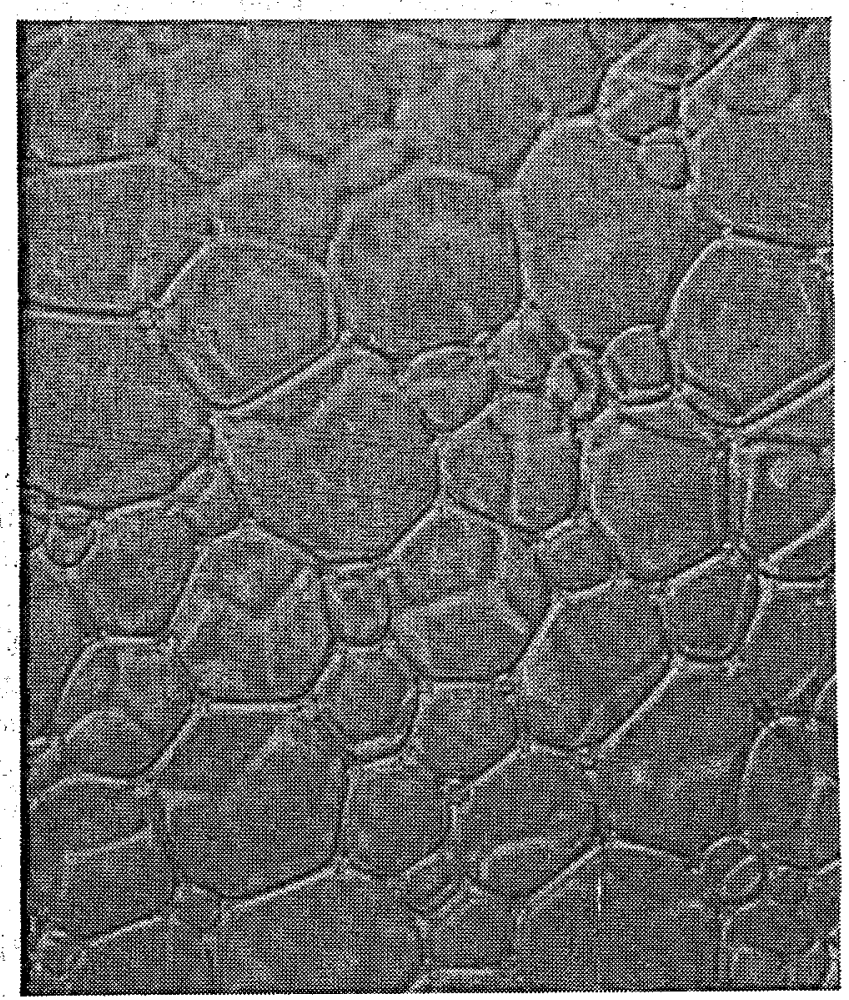

(c) After $32 \min 11 \mathrm{~s}$

Figure 2. Microphotographs of Foam Sample at Different Times After It Was Drawn 


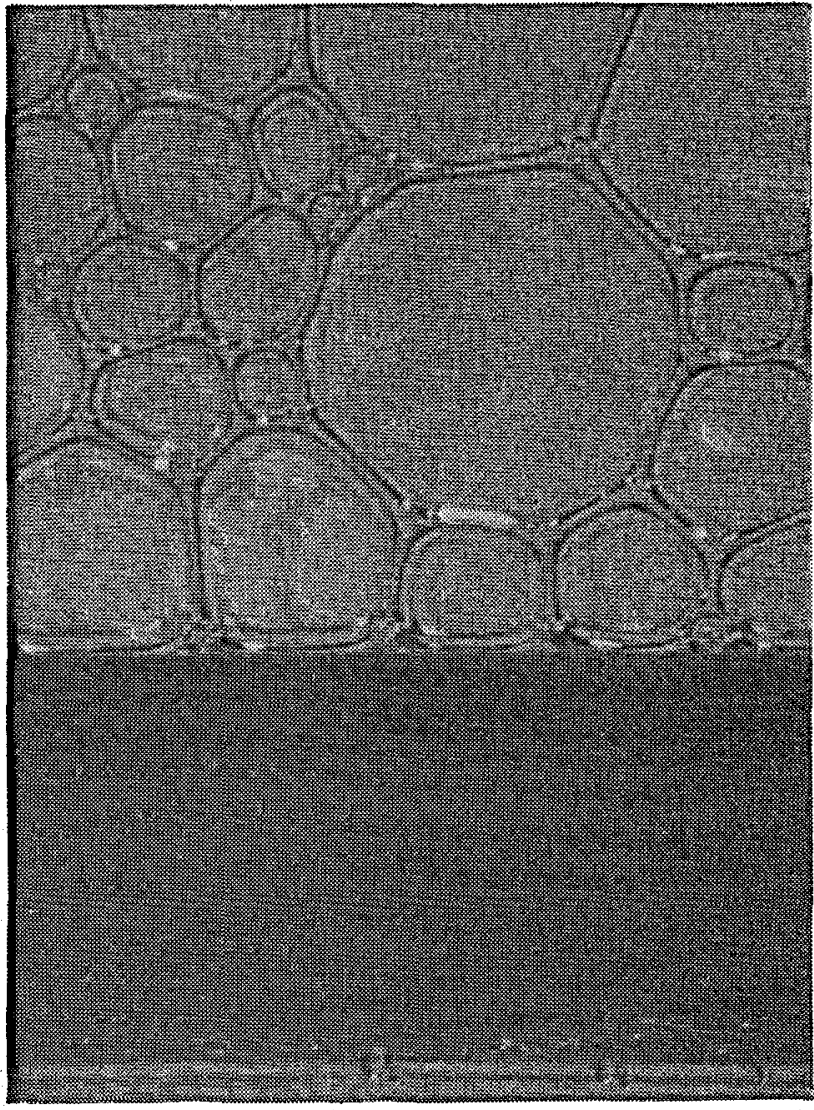

Figure 3. Microphotograph of the Foam-Solid Interface

\section{Theoretical Pressure- Drop/Flow-Rate Model}

It has been proposed by numerous investigators that aqueous foams exhibit a yield stress. ${ }^{5,6}$ In a pipeflow geometry, the existence of a yield stress indicates that when the local shear stress is below the yield stress the foam will flow as a solid. Near the centerline where the shear stress goes to zero, foam will move as a plug and the velocity gradient will be zero. In the wall region where the shear stress is largest, a velocity gradient will be present. Some investigators have modeled foams as a Bingham plastic;, ${ }^{5,6}$ the stress above the yield stress is linearly proportional to the velocity gradient

$\tau-\tau_{\mathbf{y}}=-\eta \frac{\mathrm{du}}{\mathrm{dr}}$

where $\tau$ is local shear stress, $\tau_{y}$ is the yield stress, $\eta$ is viscosity, $\mathrm{u}$ is velocity, and $\mathrm{r}$ is radial position.
Other investigators have assumed foam to behave as a "power-law" fluid." A combination of the "powerlaw" fluid and the Bingham plastic is the BulkleyHerschel model

$\tau-\tau_{y}=-\eta\left(\frac{r_{w}}{\bar{a}} \frac{d u}{d r}\right)^{n-1} \frac{d u}{d r}$

where $\bar{u}$ is the average velocity, $r_{w}$ is the pipe radius, and $n$ is an exponent. If $\tau_{y}$ is zero and $n=1$, then the Bulkley-Herschel model reduces to the laminar Newtonian model.

The quantity $\left(r_{w} / u d u / d r\right)$ raised to the exponent $(n-1)$ is dimensionless; hence, $\eta$ has the units of viscosity $\left(\mathrm{FT} / \mathrm{L}^{2}\right)$. This approach appears to offer some advantage over that in the literature in which the units of $\eta$ depend on the value of the "power-law" exponent.

The flow-rate/pressure-drop relationship can be developed from the momentum equation for steady and fully developed pipe flow:

$\frac{1}{r} \frac{d}{d r}(r)=\frac{\Delta p}{L}$

where $\Delta \mathrm{p} / \mathrm{L}$ is the pressure drop per unit length. This equation can be integrated from the centerline to any arbitrary radius to yield.

$\tau=\Delta \mathrm{pr} / 2 \mathrm{~L}$

or

$\tau=\mathrm{r} \tau_{\mathrm{w}} / \mathrm{r}_{\mathrm{w}}$

Equation (4) can be solved for the velocity gradient to yield

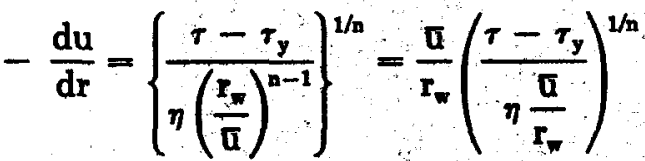

Integrating Equation (8) from the wall to an arbitray position $\mathrm{r}$ while using Equation (7), the velocity profile can be written as

$\frac{u}{u_{\max }}= \begin{cases}1-\left(\frac{r^{+}-c}{1-c}\right)^{m+1} & r^{+\geq c} \\ 1 & r^{+}<c\end{cases}$ 
where $r^{+}=r / r_{w}, m=1 / n$, and $c=\tau_{y} / \tau_{w}=r_{y} / r_{w}$. The average velocity is found to be

$$
\begin{aligned}
& \frac{u}{u_{\max }}=1-\frac{2(1-c)}{m+2}+\frac{2(1-c)^{2}}{(m+2)(m+3)} \\
& =c^{2}+2 c(1-c) \frac{m+1}{m+2}+(1-c)^{2} \frac{m+1}{m+3}
\end{aligned}
$$

Combining Equations (9) and (10), the dimensionless velocity profile can be experssed as

$$
\begin{aligned}
& u^{+}=\frac{u}{u}= \\
& \frac{1-\left(\frac{r^{+}-c}{1-c}\right)^{m+1}}{1-2\left(\frac{1-c}{m+2}\right)+2 \frac{(1-c)^{2}}{(m+2)(m+3)}} r^{+} \geq c \\
& \frac{1}{1-2\left(\frac{1-c}{m+2}\right)+2 \frac{(1-c)^{2}}{(m+2)(m+3)}} r^{+}<c
\end{aligned}
$$

Figures 4 and 5 present dimensionless velocity profiles obtained from Equation (11). Figure 4 is for the Bingham plastic $(m=n=1.0,0 \leq c \leq 1.0)$. In dimensionless coordinates, the size of the plug flow region is given by $\mathbf{r}^{+}=$c. The laminar Newtonian velocity profile is the $c=0$ curve. As $c$ increases, the magnitude of the dimensionless velocity gradient at the wall also increases. Figure 5 shows the impact of the powerlaw exponent on the dimensionless velocity profile for two different values of $c$. As $m$ increases $(n=1 / m$ dtcreases), the magnitude of the dimensionless velocity gradient at the wall increases. Increasing $m$ also increases the extent of the constant velocity region in the center portion of the pipe. A convenient frictionfactor/Reynolds-number relationship can be written as

$\mathrm{fRe}=$

$$
\left\{\frac{\left(1-\frac{B}{f R e}\right)^{m+1}}{m+1}\left[1-\frac{2\left(1-\frac{B}{f R e}\right)}{m+2}+\frac{2\left(1-\frac{B}{f R e}\right)^{2}}{(m+2)(m+3)}\right]\right\}^{1 / m}
$$

where $B$ is a dimensionless yield stress, and the other parameters in Equation (12) are defined as

$$
\begin{aligned}
& f=\frac{\mathrm{D} \Delta \mathrm{p} / \mathrm{L}}{\rho \frac{\mathrm{u}^{2}}{2}} \\
& \mathrm{~B}=\frac{8 \tau_{\mathrm{y}} \mathrm{D}}{\eta \overline{\mathrm{u}}} \\
& \mathrm{Re}=\frac{\rho \overline{\mathrm{uD}}}{\eta} \\
& \mathrm{c}=\frac{\mathrm{B}}{\mathrm{fRe}} \\
& \tau_{\mathrm{w}}=\frac{\mathrm{f}}{4} \frac{\rho \mathrm{u}^{2}}{2}
\end{aligned}
$$

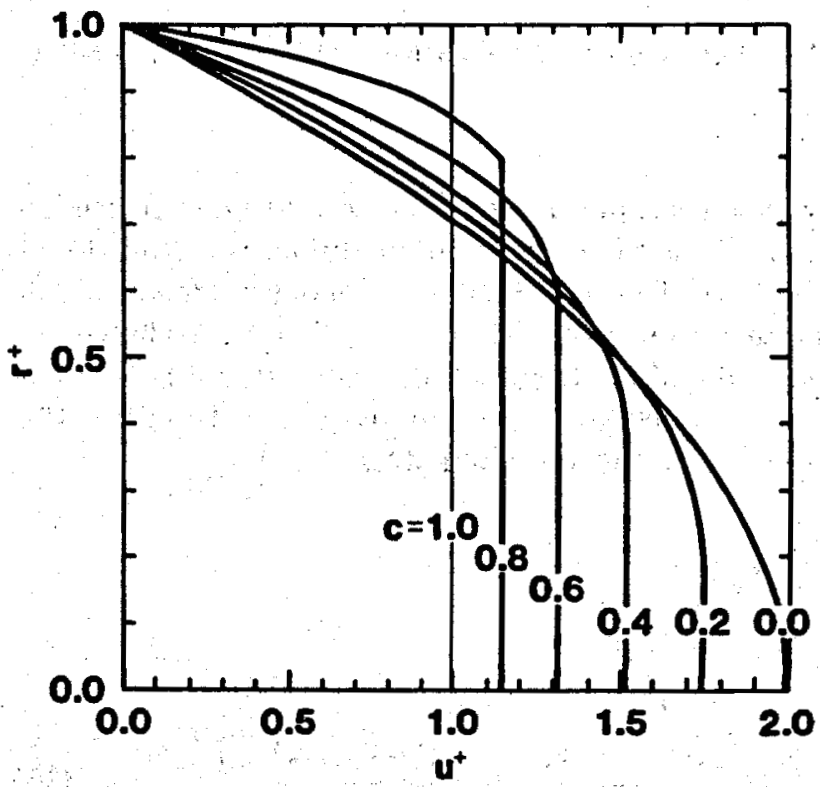

Figure 4. Dimensionless Velocity Profiles for a Bingham Plastic $(n=1,0 \leq c \leq 1)$ 


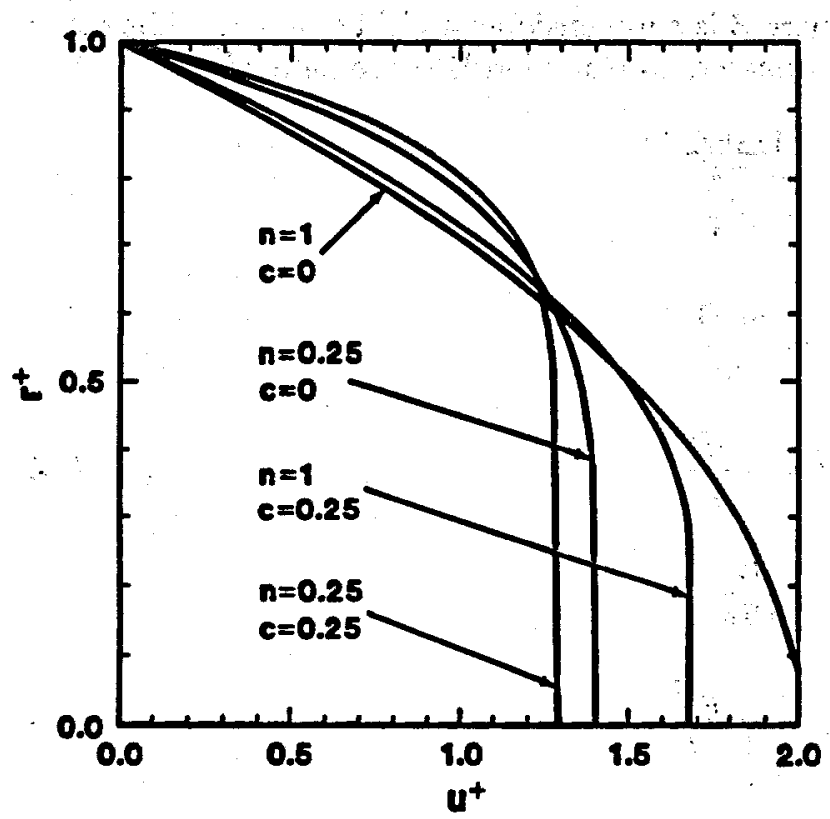

Figure 5. Dimensionless Velocity Profiles for a Power-Law Fluid

Figure 6 presents the results of Equation (12) graphically. For laminar Newtonian fluids, the traditional value $\mathrm{fRe}=64$ is obtained. As $\mathrm{c}$ increases from 0 to 0.3 , fRe increases from 64 to 103 . The data shown on Figure 6 will be discussed in a subsequent section:

An important equation used in estimating the viscosity $(\eta)$ and the yield stress $\left(\tau_{y}\right)$ is

$$
\begin{aligned}
& \mathrm{u}=\frac{\tau_{\mathrm{w}} \mathrm{r}_{\mathrm{w}}}{\eta} \\
& \times\left\{\frac{\left(1-\tau_{\mathrm{y}} / \tau_{\mathrm{w}}\right)^{\mathrm{m+1}}}{\mathrm{m}+1}\right. \\
& \left.\times\left[1-\frac{2\left(1-\tau_{\mathrm{y}} / \tau_{\mathrm{w}}\right)}{\mathrm{m}+2}+\frac{2\left(1-\tau_{\mathrm{y}} / \tau_{\mathrm{w}}\right)^{2}}{(\mathrm{~m}+2)(\mathrm{m}+3)}\right]\right]^{1 / \mathrm{m}} .
\end{aligned}
$$

When $\tau_{\mathrm{y}} / \tau_{\mathrm{w}} \ll 1, \mathrm{u}$ is approximately linear in $\tau_{\mathrm{w}}$. This linearity is more clearly evident for the Bingham plastic model. For the Bingham plastic $(m=1)$, Equation (14) reduces to

$\bar{u}=\frac{\tau_{w} r_{w}}{4 \eta}\left[1-\frac{4}{3} \frac{\tau_{y}}{\tau_{w}}+\frac{1}{3}\left(\frac{\tau_{y}}{\tau_{w}}\right)^{4}\right]$.

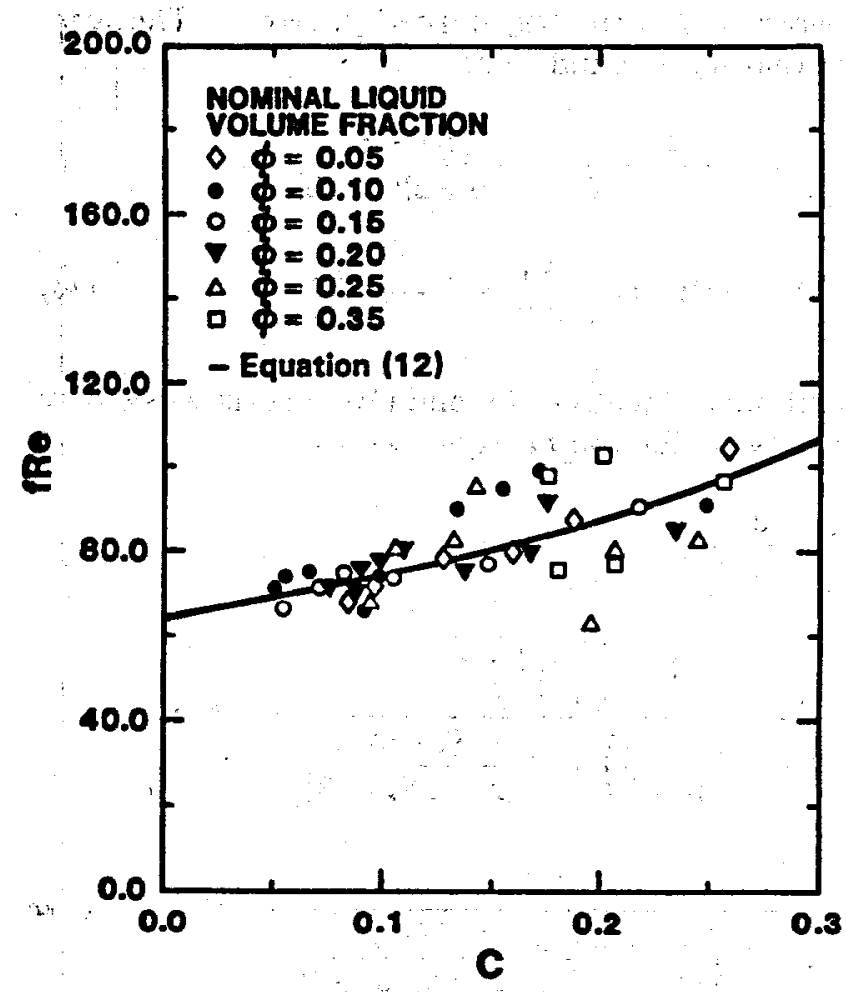

Flgure 6. Dependence of the Friction-Factor/ReynoldsNumber.Relationship Upon the Yield-Stress/Wall-ShearStress Ratio

\section{Analysis of the Data}

Pressure-drop measurements were taken for liquid volume fractions ranging between 0.05 and 0.35 and average velocities between 0.12 and $0.80 \mathrm{~m} / \mathrm{s}(0.4$ and $2.6 \mathrm{ft} / \mathrm{s}$ ). The liquid volume fraction range is that of practical interest for geothermal drilling applications; the velocity range is limited by the maximum and minimum possible mass flow rates of air or the liquid. The velocity range also corresponds to that of practical interest; the field application, however, has a larger pipe radius and, therefore, will have larger Reynolds numbers. Since foam is very viscous, the maximum Reynolds number for the data of the present study is less than 100; the corresponding hydrodynamic entry length is less than five tube diameters or $130 \mathrm{~mm}$ ( $5 \mathrm{in}$.). Therefore, the flow can be considered laminar and hydrodynamically fully developed everywhere between the pressure measurement ports. 
The total pressure drop across a $2.44-\mathrm{m}(8.00-\mathrm{ft})$ length of the $3.00-\mathrm{m}(9.83-\mathrm{ft})$ long by $25.88-\mathrm{mm}$ (1.019-in.) ID test section is measured with a differential pressure transducer; a separate differential pressure transducer is used in conjunction with an atmospheric pressure gauge to measure the static pressure at the center of the test section length. This static pressure measurement is used to determine various foam properties including the liquid volume fraction. Preliminary experiments with the test section horizontal indicated that liquid drainage affected the test results; hence, the test section is oriented vertically. A more detailed description of the experimental apparatus is found in the Appendix.

The total pressure change consists of hydrostatic and frictional components. The frictional pressure drop is given by

$\Delta \mathrm{p}_{\mathrm{f}}=\Delta \mathrm{p}+\rho \mathrm{gh}$

where $\Delta p_{f}$ is the frictional pressure drop, $\Delta p$ is the total (or measured) pressure drop, $\rho$ is the foam density, $g$ is the acceleration due to gravity, and $h(>0)$ is the vertical distance between the pressure ports. The frictional pressure drop is related to the wall shear stress through the momentum balance given by Equation (6):

$\tau_{w}=\Delta \mathrm{p}_{\mathrm{f}} \mathrm{r}_{\mathrm{w}} / 2 \mathrm{~L}$

The average foam velocity is found from the mass flow rate of the air, the volumetric flow rate of the liquid plus its density, and the cross-sectional area of the tube via the continuity equation.

The average velocity versus wall shear stress data for the entire range of liquid volume fractions and mass flow rates are shown in Figure 7 and given in Table 1. The curves included on Figure 7 will be explained later.

The relative uncertainty in the frictional pressure drop can be expressed as

$\frac{\delta\left(\Delta p_{f}\right)}{\Delta p_{f}}=\left[\frac{(\delta \Delta p)^{2}}{\Delta p_{f}^{2}}+\frac{(\delta(\rho g h))^{2}}{\Delta p_{f}^{2}}\right]^{1 / 2}$

The most important source of uncertainty is the variability in the pressure-drop measurements, which is approximately $6 \%$ of the measured value. Hence, the relative uncertainty in the frictional pressure drop is proportional to the ratio $\left(\Delta \mathrm{p} / \Delta \mathrm{p}_{\mathrm{f}}\right)$. This ratio is tabulated in Table 1. This source of uncertainty is the smallest for small values of the total pressure drop. Small values of $\Delta p$ often occur when the frictional and hydrostatic pressure drops are approximately equal. This condition exists for the midrange liquid volume fractions at certain flow rates (see Table 1). Large uncertainties result if the hydrostatic pressure drop is much larger than the frictional pressure drop. The foam is relatively dense for $\phi=0.35$, resulting in a larger value for $\left|\Delta p / \Delta p_{f}\right|$. Consequently, the uncertainty associated with $\phi=0.35$ is large, on the order of $20 \%$.

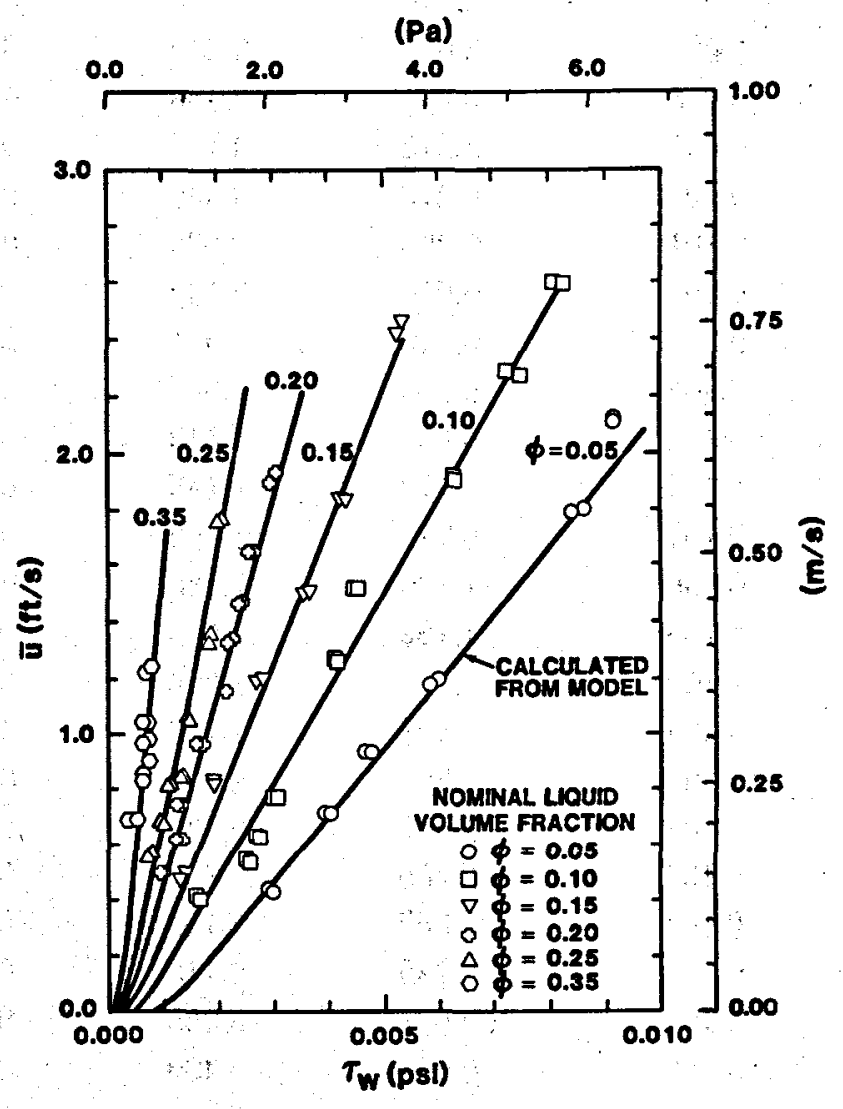

Figure 7. Relationship of Average Velocity to the Wall Shear Stress 


\section{Table 1. Summary of Pressure-Drop Measurements}

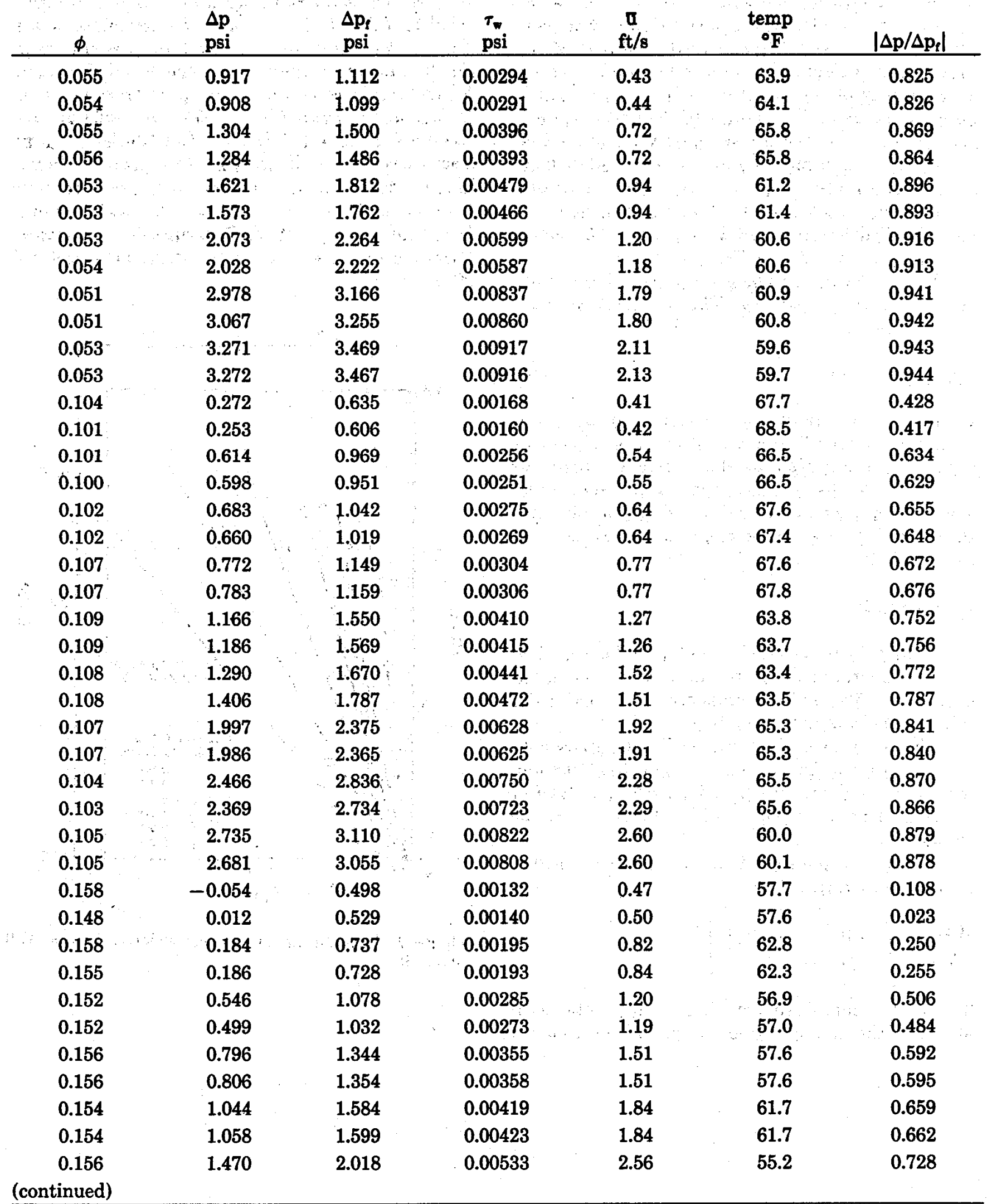


Table 1 (concluded)

\begin{tabular}{|c|c|c|c|c|c|c|}
\hline$\phi$ & $\begin{array}{l}\Delta p \\
\text { psi }\end{array}$ & $\begin{array}{l}\Delta \mathrm{p}_{\mathrm{f}} \\
\mathrm{psi}\end{array}$ & $\begin{array}{l}\tau_{\text {w }} \\
\text { psi }\end{array}$ & $\begin{array}{c}\mathrm{u} \\
\mathrm{ft} / \mathrm{s}\end{array}$ & $\begin{array}{c}\text { temp } \\
{ }^{\circ} \mathrm{F}\end{array}$ & $\left|\Delta \mathrm{p} / \Delta \mathrm{p}_{\mathrm{f}}\right|$ \\
\hline 0.159 & 1.414 & 1.975 & 0.00522 & 2.52 & 55.4 & 0.716 \\
\hline 0.197 & -0.305 & 0.380 & 0.00101 & 0.50 & 66.1 & 0.803 \\
\hline 0.196 & -0.324 & 0.360 & 0.00095 & 0.50 & 66.3 & 0.900 \\
\hline 0.204 & -0.218 & 0.492 & 0.00130 & 0.63 & 63.6 & 0.443 \\
\hline 0.197 & -0.173 & 0.512 & 0.00135 & 0.65 & 63.7 & 0.338 \\
\hline 0.204 & -0.179 & 0.515 & 0.00136 & 0.75 & 68.0 & 0.350 \\
\hline 0.205 & -0.221 & 0.492 & 0.00130 & 0.75 & 68.1 & 0.449 \\
\hline 0.205 & -0.090 & 0.623 & 0.00165 & 0.97 & 66.9 & 0.144 \\
\hline 0.198 & -0.060 & 0.632 & 0.00167 & 0.97 & 66.9 & 0.095 \\
\hline 0.198 & 0.136 & 0.828 & 0.00219 & 1.16 & 60.1 & 0.164 \\
\hline 0.198 & 0.137 & 0.827 & 0.00219 & 1.16 & 60.0 & 0.166 \\
\hline 0.206 & 0.151 & 0.869 & 0.00230 & 1.34 & 60.0 & 0.174 \\
\hline 0.206 & 0.108 & 0.828 & 0.00219 & 1.33 & 60.2 & 0.130 \\
\hline 0.204 & 0.239 & 0.951 & 0.00251 & 1.47 & 57.6 & 0.251 \\
\hline 0.204 & 0.202 & 0.915 & 0.00242 & 1.47 & 57.6 & 0.221 \\
\hline 0.206 & 0.262 & 0.979 & 0.00259 & 1.65 & 60.7 & 0.268 \\
\hline 0.205 & 0.277 & 0.995 & 0.00263 & 1.65 & 60.7 & 0.278 \\
\hline 0.207 & 0.411 & 1.134 & 0.00300 & 1.90 & 56.4 & 0.362 \\
\hline 0.205 & 0.427 & 1.142 & 0.00302 & 1.93 & 56.0 & 0.374 \\
\hline 0.257 & -0.634 & 0.259 & 0.00069 & 0.56 & 66.3 & 2.448 \\
\hline 0.252 & -0.586 & 0.291 & 0.00077 & 0.57 & 66.3 & 2.014 \\
\hline 0.249 & -0.520 & 0.349 & 0.00092 & 0.69 & 54.2 & 1.490 \\
\hline 0.250 & -0.491 & 0.380 & 0.00100 & 0.68 & 55.0 & 1.292 \\
\hline 0.250 & -0.454 & 0.419 & 0.00111 & 0.82 & 51.6 & 1.084 \\
\hline 0.250 & -0.432 & 0.439 & 0.00116 & 0.82 & 51.6 & 0.984 \\
\hline 0.253 & -0.381 & 0.499 & 0.00132 & 0.85 & 64.6 & 0.764 \\
\hline 0.252 & -0.365 & 0.512 & 0.00135 & 0,85 & 64.9 & 0.713 \\
\hline 0.250 & -0.321 & 0.547 & 0.00145 & 1.06 & 64.5 & 0.587 \\
\hline 0.247 & -0.324 & 0.537 & 0.00142 & 1.07 & 64.5 & 0.603 \\
\hline 0.245 & -0.162 & 0.692 & 0.00183 & 1.33 & 62.6 & 0.234 \\
\hline 0.244 & -0.147 & 0.705 & 0.00186 & 1.34 & 64.5 & 0.209 \\
\hline 0.247 & -0.085 & 0.775 & 0.00205 & 1.77 & 61.0 & 0.114 \\
\hline 0.248 & -0.110 & 0.754 & 0.00199 & 1.76 & 61.2 & 0.146 \\
\hline 0.356 & -1.032 & 0.204 & 0.00054 & 0.70 & 70.7 & 5.059 \\
\hline 0.357 & -1.112 & 0.129 & 0.00034 & 0.70 & 70.6 & 8.620 \\
\hline 0.357 & -0.979 & 0.260 & 0.00069 & 0.84 & 62.3 & 3.765 \\
\hline 0.349 & -0.928 & 0.304 & 0.00080 & 0.98 & 62.3 & 3.003 \\
\hline 0.354 & -0.954 & 0.278 & 0.00073 & 0.97 & 63.4 & 3.432 \\
\hline 0.346 & -0.942 & 0.260 & 0.00069 & 1.04 & 64.0 & 3.623 \\
\hline 0.343 & -0.910 & 0.282 & 0.00074 & 1.04 & 64.1 & 3.227 \\
\hline 0.349 & -0.915 & 0.296 & 0.00078 & 1.23 & 62.0 & 3.091 \\
\hline 0.352 & -0.910 & 0.313 & 0.00083 & 1.24 & 61.4 & 2.907 \\
\hline
\end{tabular}


From the assumed relationship between the average foam velocity and the wall shear stress, Equation (14), the viscosity and yield stress for a given nominal liquid volume fraction can be estimated. A nonlinear parameter estimation program (NLINA) ${ }^{8}$ was used to fit the experimental data to the model relationship, Equation (14). NLINA determines the values of the parameters that produce the minimum sum of squares of the differences between the model and the experimental data. Although there are three unknown parameters [viscosity, yield stress, and the power-law exponent (m or $n)$ ], all three cannot be determined independently because their sensitivity coefficients are not independent. The exponent, therefore, is specified and the other two parameters (viscosity and yield stress) are estimated. Numerical calculations indicated that the exponent, $n$, and the viscosity, $\eta$, are coupled. The preferred value for the exponent is that which results in the minimum sum of the squares of the errors.

The sum-of-squares error, $\mathrm{S}$, is given in Table 2. The variation of $S$ with $m$ is very small, and there is no clear value of $m$ which results in a minimum value of $S$ for all liquid volume fractions. Since $n=1$ results in a much simpler model (Bingham plastic model), unity is preferred for the exponent. The insensitivity of $S$ to the assumed exponent, $n$, indicates that this experiment cannot be used to estimate $n$. Velocity profile measurements would be helpful but would be more complicated than the pressure drop measurements. Incidentally, data for $\phi=0.35$ is deleted from Table 2 because of the limited range of the data and large relative uncertainty.
Figures 8 and 9 show the variation of the Bingham plastic $(n=1)$ viscosity and yield stress with the nominal liquid volume fraction. Viscosity has an apparent exponential variation, whereas yield stress has an apparent logarithmic variation with liquid volume fraction. Utilizing these assumed variations, the following relationships were determined using NLINA for a Bingham plastic with variable liquid volume fraction:

$$
\begin{aligned}
\eta & =0.4304 \mathrm{e}^{-6.838 \phi} \mathrm{N} \cdot \mathrm{s} / \mathrm{m}^{2} \\
& =0.008989 \mathrm{e}^{-6.838 \phi} \quad \mathrm{lb}_{\mathrm{f}} \cdot \mathrm{s} / \mathrm{ft}^{2} \\
\tau_{\mathrm{y}} & =0.3773 \phi^{-0.8994} \mathrm{~Pa} \\
& =5.472 \times 10^{-5} \phi^{-0.8994} \mathrm{psi}
\end{aligned}
$$

where $\phi$ is the liquid volume fraction. Equations (18) and (19) should be restricted to the liquid volume range of the present study $(0.05 \leq \phi \leq 0.35)$. These equations are also limited to foam similar to that utilized for the experiments reported here; i.e., the water/surfactant ratio must be equal to that used $(0.01)$ and the methods of foam generation should be similar. For the present study, the absolute pressure ranged between $170 \mathrm{kPa}$ (25 psia) and $400 \mathrm{kPa}(60$ psia). The foam temperature was essentially room temperature for all tests; temperature dependence of these properties has not been considered.

\section{Table 2. Sum-of-Squares Error for Various Exponents}

\begin{tabular}{cccccc} 
& \multicolumn{6}{c}{ Nominal Liquid Volume Fractions } \\
$\mathrm{m}=1 / \mathrm{n}$ & 0.05 & 0.10 & 0.15 & 0.20 & 0.25 \\
\hline 0.5 & 0.02907 & 0.13107 & 0.04918 & 0.07477 & 0.15208 \\
0.9 & 0.02903 & 0.13096 & 0.04888 & 0.07444 & 0.15167 \\
1.0 & 0.02903 & 0.13095 & 0.04884 & 0.07440 & 0.15149 \\
1.1 & 0.02902 & 0.13095 & 0.04881 & 0.07437 & 0.15157 \\
1.5 & 0.02901 & 0.13095 & 0.04873 & 0.07429 & 0.15147 \\
2.0 & 0.02901 & 0.13096 & 0.04869 & 0.07425 & 0.15141 \\
2.5 & 0.02900 & 0.13097 & 0.04867 & 0.07424 & 0.15139 \\
3.0 & 0.02900 & 0.13099 & 0.04866 & 0.07424 & 0.15138 \\
4.0 & 0.02900 & 0.13101 & 0.04867 & 0.07425 & 0.15139 \\
10.0 & 0.02900 & 0.13109 & 0.04874 & 0.07434 & 0.15149
\end{tabular}




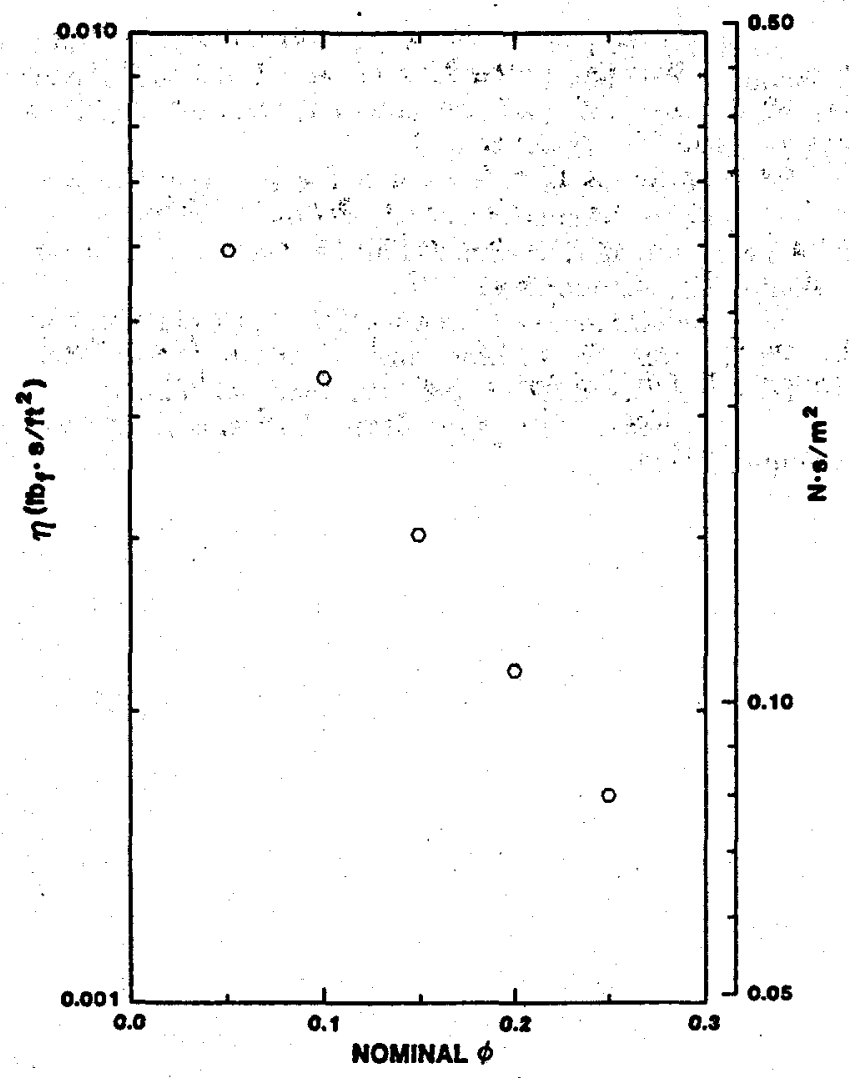

Figure 8. Variation of the Bingham Plastic Viscosity With Liquid Volume Fraction

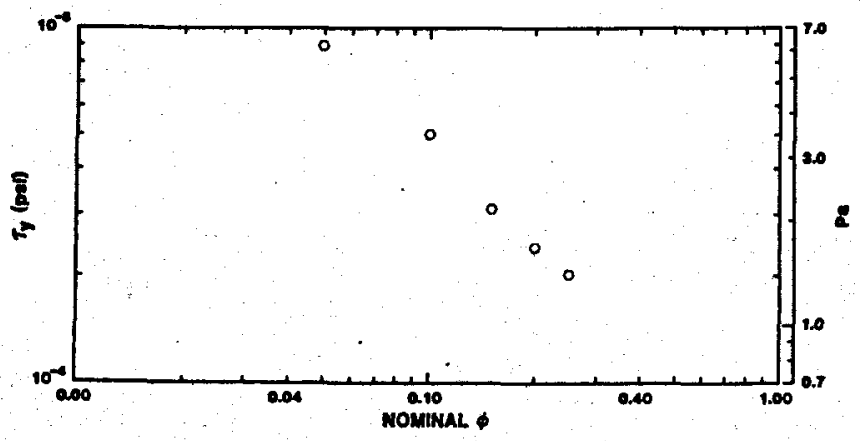

Figure 9. Variation of the Bingham Plastic Yield Stress With Liquid Volume Fraction

The curves for the various nominal liquid volume . fractions on Figure 7 were determined by substituting the above viscosity and yield-stress relationships into the Bingham plastic average-velocity/wall-shearstress relationship [Equation (15)]. If the yield stress is very small compared to the wall shear stress, the relationship between the average velocity and the wall shear stress is nearly linear; the curves of Figure 7 exhibit this approximately linear region. The theoretical relationship is curved in the region in which the yield stress is greater than about $35 \%$ of the wall shear stress. The yield stress for a particular nominal liquid volume fraction is represented on Figure 6 by the point at which a curve intersects the $x$-axis (the wallshear-stress axis). Since the experimental data falls in the linear portion, the extent of the curved region is not well defined, and hence the viscosity is known with greater certainty than the yield stress. The range of practical interest is also in the linear region; therefore, the uncertainty in the yield stress should not be too important for the pressure-drop predictions for field applications. It is expected that Equations (15), (18), and (19) can be used to extrapolate to higher wall-shear-stress values of field applications without difficulty.

Since the curves on Figure 7 were determined for the nominal liquid volume fractions, much of the scatter from these lines can be accounted for by the scatter in the actual liquid volume fraction. For example, most of the data of Figure 7 for a liquid volume fraction of 0.05 lies above the solid line. This bias is because the actual liquid volume fraction was consistently above the nominal liquid volume fraction. The actual liquid volume fraction is always within 0.01 of the nominal value. The actual liquid volume fractions for the data are given in Table 1.

Equations (18) and (19) were also used in conjunction with Equation (13) to determine the data points on Figure 6. The scatter at large $c$ values results primarily from the relatively large uncertainty associated with $\phi=0.35$ and the lower flow rates for $\phi=$ 0.25 .

\section{Conclusions}

Pressure-drop measurements from the Foam Flow Heat Transfer Loop have been presented. Experimentally determined average-velocity versus wall-shearstress data can be correlated with the stress-strain model for a power-law, yield-stress fluid. The correlation is equally as good for exponents $(n)$ between 0.25 and unity; the Bingham plastic model $(n=1)$ is chosen for its simplicity. Velocity-profile measurements would be useful in determining the best model for the stress-strain relationship for foam. For the Bingham plastic model, viscosity has an exponential variation with liquid volume fraction, whereas yield stress varies logarithmically with liquid volume fraction. Further work is needed to determine the effect of such quantities as foam-generator pressure, weight-percent surfactant, and temperature on viscosity and yield stress. 


\section{References}

'B. F. Blackwell and K. B. Sobolik, An Experimental Investigation of the Hydrodynamic and Heat-Transfer Behavior of Aqueous Foam in Laminar Tube Flow, SAND85-1922 (Albuquerque, NM: Sandia National Laboratories, to be published).

2J. J. Bikerman, Foams (New York: Springer-Verlag, 1973).

${ }^{3}$ A. David and S. S. Marsden, "The Rheology of Foam," SPE Paper No. 2544, Presented at 44th Annual Fall Meeting of SPE in Denver, CO, September 28 - October 1, 1969.

P. B. Rand and A. M. Kraynik, "The Drainage of Aqueous Foams: Generation-Pressure and Cell Size Effects," SPE Journal, February 1983, pp 152-154.
AA. H. Beyer, R. S. Millhone, and R. W. Foote, "Flow Behavior of Foam as a Well Circulating Fluid," SPE Paper No. 3986, Presented at 47th Annual Fall Meeting of SPE in San Antonio, TX, October 8-11, 1972.

'R. S. Millhone, C. A. Haskin, and A. H. Beyer, "Factors Affecting Foam Circulating in Oil Wells," SPE Paper No. 4001, Presented at 47th Annual Fall Meeting of SPE in San Antonio, TX, October 8-11, 1972.

${ }^{7}$ V. Sanghani and C. U. Ikoku, "Rheology of Foam and Its Implications in Drilling and Cleanout Operations," ASME J.E.R.T.,Vol 105, September 1983, pp 362-371.

${ }^{8}$ J. V. Beck, Michigan State University. Private communication. 


\section{APPENDIX}

\section{Description of the Experimental Apparatus}

A schematic of the experimental apparatus is shown in Figure A-1. The apparatus was designed primarily for heat-transfer foam flow experiments. The test section is basically a counterflow heat exchanger consisting of a $3.00-\mathrm{m}(9.84-\mathrm{ft})$ long by $2.588-$ $\mathrm{cm}$ (1.019-in.) ID stainless-steel tube with wall thickness of $0.6033 \mathrm{~cm}(0.2375 \mathrm{in}$.) and concentric within a $5.458-\mathrm{cm}-\mathrm{ID}$ steel (nominal 2-in. IPS schedule 20) pipe. For heat-transfer measurements, hot water is circulated through the resulting $1.664-\mathrm{cm}(0.655-\mathrm{in}$.) annulus; for pressure-drop measurements, however, the hot water loop is inactive. Foam flows vertically downward through the inner tube.

The hot water loop consists of a $15-\mathrm{kW}$ electric heater, two circulation pumps in series, and a turbine flow meter. Water temperature is controlled by varying the amount of electrical power supplied to the heater. Thermocouples are used to measure the temperature at the inlet and the outlet of the heater. The volumetric flow rate is typically around $0.5 \ell / \mathrm{s}$ (8 gpm). The hot water enters the annulus at a right angle through two pipes that are $180^{\circ}$ apart; the outlet has a similar configuration. Individually calibrated RTDs (resistance temperature devices) in each of the inlets and outlets of the test section annulus are used to measure the hot water temperatures, which are typically around $50^{\circ} \mathrm{C}\left(120^{\circ} \mathrm{F}\right)$ for heat-transfer tests. Due to the large capacity rate of the water flow compared to that of the foam flow, the foam boundary condition is nearly isothermal. For "cold flow" pressure-drop tests, the hot water loop is inactive; the temperatures of the foam and the water in the inactive hot water loop are about room temperature (see Table 1).

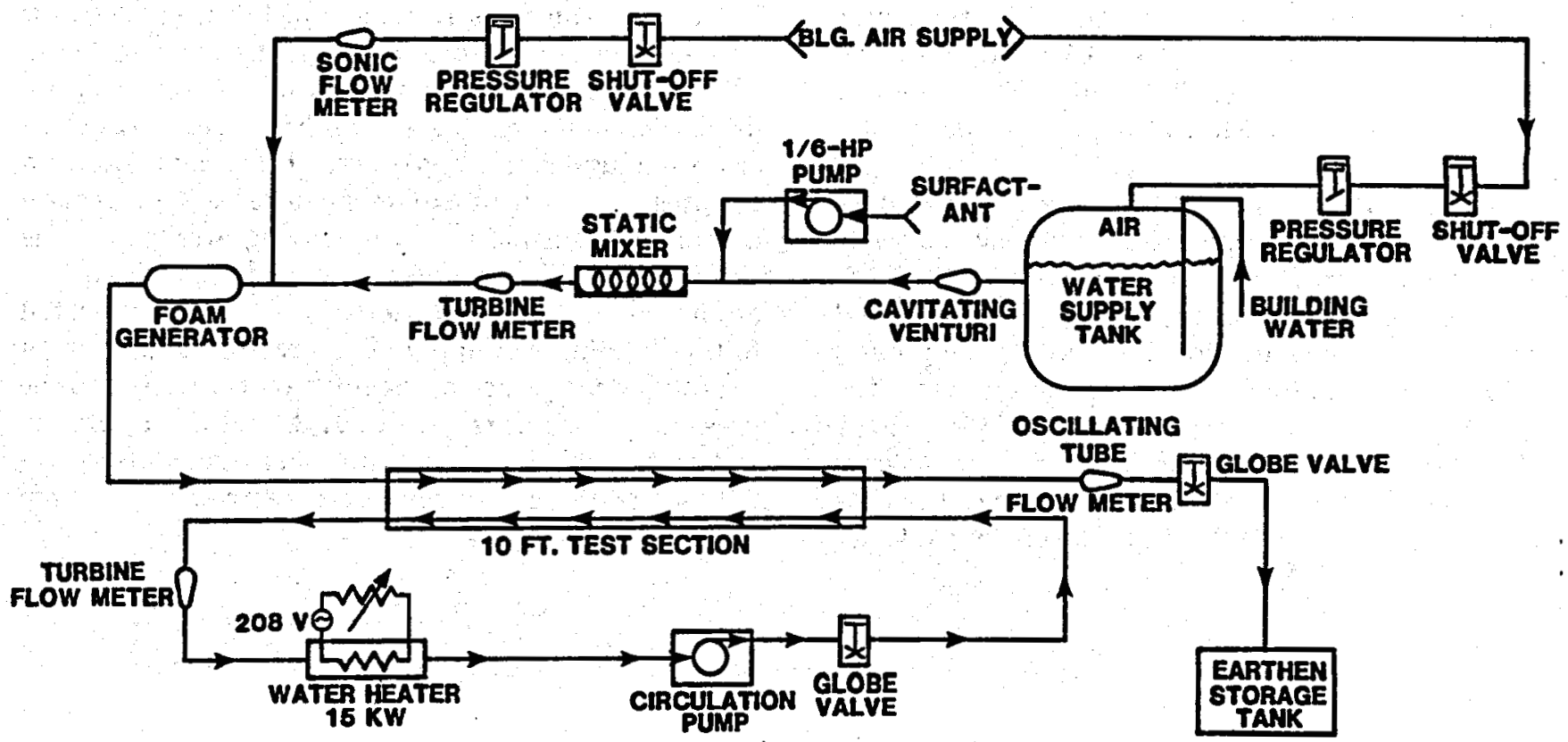

Figure A-1. Schematic of the Experimental Apparatus 
Air is combined with a water/surfactant mixture in the correct proportions to produce foam with the desired liquid volume fraction. Air is drawn from the large building supply tanks, which are maintained at 6.89 bars (100 psi). The mass flow rate is determined by the combination of a sonic flow nozzle and an upstream pressure regulator. Provided the flow is sonic at the throat, the mass flow rate of the air is held constant regardless of downstream pressure fluctuations. A series of nozzles manufactured by Flow-dyne Engineering, Inc., with diameters ranging $0.343 \mathrm{~mm}$ to $1.40 \mathrm{~mm}(0.0135 \mathrm{in}$. to $0.055 \mathrm{in}$.) provide for a range of mass flow rates.

Water is drawn from a $570 \ell$ ( $150 \mathrm{gal})$ tank that is pressurized to a maximum of 6.89 bars ( 100 psi) with building air. The water volumetric flow rate is controlled with a cavitating venturi from Fox Valve Development Corporation; due to the constant upstream pressure, the cavitating venturi provides a constant flow rate similarly to the sonic nozzle on the gas side. Surfactant is supplied from a $200 \ell$ (55 gal) barrel with a variable-stroke positive-displacement pump. The pump has two adjustable stoke heads with a maximum capacity of $3.5 \mathrm{ml} / \mathrm{s}(3.4 \mathrm{gph})$ per head. The volumetric flow rate of surfactant is always maintained at 0.01 of the water volumetric flow rate. The water and surfactant pass through a static mixer (TAH Corporation) to blend the two constituents. The liquid flow passes through one of two parallel turbine meters. These meters are manufactured by Flow Technologies, Inc. The larger capacity meter has a range of 0 to $0.158 \ell / \mathrm{s}$ (0 to $2.5 \mathrm{gpm})$; the other, with a range of 0 to $0.0315 \mathrm{\ell} / \mathrm{s}$ ( 0 to $0.5 \mathrm{gpm}$ ), provides greater accuracy at lower flow rates. The range of liquid flow rates is 0.00315 to $0.0632 \ell / \mathrm{s}(0.05$ to 1.00 gpm).

The gas and liquid flows are mixed immediately upstream of the foam generator. Experience suggests that vertical foam flow with the air injected at the bottom of the foam generator and the liquid injected horizontally will produce foam of acceptable quality. Steel wool in the air line prior to the point at which the air is injected into the liquid flow provides a fairly uniform pressure at this point. The foam generator is a packed bed of copper wool in a vertical circular tube with an ID of $3.468 \mathrm{~cm}$ (1.365 in.). The packing density is $0.56 \mathrm{~g} / \mathrm{cm}^{8}\left(34.7 \mathrm{lb}_{\mathrm{m}} / \mathrm{ft}^{3}\right)$ and the packing length is $11.43 \mathrm{~cm}$ (4.5 in.).

After leaving the generator, the foam enters the test section. The test section is mounted vertically in a $22 \mathrm{~cm}$ by $23 \mathrm{~cm}$ ( 8 in. by 8.5 in.) cross-section by 1.9 cm (0.75-in.) thick wood box. The vertical orientation minimizes foam drainage problems; the foam flows downward through the test section. The cavity between the test section and the box is filled with silica aerogel insulation, which is available from W. $R$. Grace and Co., Davison Chemical Division.

The foam inlet and outlet to the test section are connected to nylon bushings that seal the annulus; the foam flows through a hole in the bushing that has the same diameter as the test section. The seals are held via a flexible bracket to the adjoining pieces, which are threaded into the bracket.

The pressure change over $\mathrm{a} 2.4-\mathrm{m}(8.0-\mathrm{ft})$ length of the test section is measured with a Validyne, Inc., variable-reluctance differential pressure transducer. Two transducers are available with ranges of 0 to 0.0862 bars ( 0 to 1.25 psid) and 0 to 0.22 bars ( 0 to 3.2 psid). A 0 to 6.89 bars (0 to 100 psi) Gould, Inc., differential pressure transducer is used to measure the static pressure at the center of the test section. All pressure transducers were calibrated at Sandia National Laboratories. The 1.59-mm (0.0625-in.) diameter stainless-steel tubes used for pressure ports penetrate the outer pipe and are held in place with gland nuts. The connection with the inner tube is sealed with an O-ring at the bottom of a counterbored hole. The pressure port has a diameter of $1.0 \mathrm{~mm}(0.040 \mathrm{in}$.).

Due to the long lines between the pressure ports and the transducers, foam tends to back up into the lines, thereby producing erroneous readings. An elaborate valving scheme was designed to flush foam from the pressure lines immediately before taking measurements. The schematic of the valving arrangement is shown in Figure A-2. Valves 2, 4, and 6 are three-way on/off valves. In one position, the lines are connected to the building air supply via a pressure regulator; in the other open position, the lines are connected to the pressure transducers. Valves 1,3 , and 5 seal off the test section during temperature measurements. Valve 7 protects the low-range pressure transducer from being over-ranged. 
$V_{1}, v_{9}, v_{5}:$ ON/OFF VALVES

$v_{2}, v_{4}, v_{6}$ : THREEWAY ON/OFF VALVES

$\triangle P_{M}:$ 0-100 PSID TRANSDUCER

$\triangle P_{L}$ : LOW RANGE DIFFERENTIAL PAESSURE TRANSDUCER

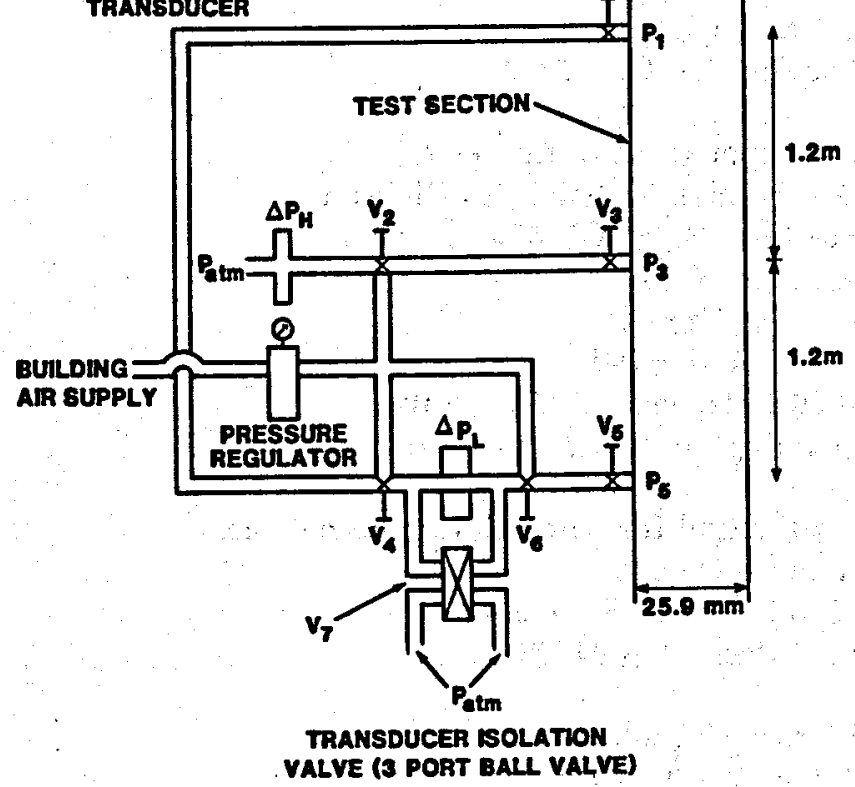

Flgure A-2. Schematic of Valving Arrangement for Flushing Pressure Measurement Lines
Individually calibrated RTDs are used to measure the foam temperature at the inlet and outlet to the test section (one each). Type $K$ thermocouples are used to measure various temperatures, such as the ambient temperature, the hot water temperature, and the temperature of the air flow at the sonic flow nozzle.

An HP 1000 series computer is used for data acquisition. Pressure readings are averaged over approximately 15 scans taken during a 1 to $1.5 \mathrm{~min}$ interval. The remaining measurements are scanned during the three pressure measurement intervals and are, therefore, averaged over approximately 45 scans. (The pressures upstream and downstream of the sonic nozzle and the static test section pressure are -measured with the same transducer). 
DISTRIBUTION:

DOE/TIC-4500, R74, UC-66d (360)

Los Alamos National Laboratory

Attn: J. C. Rowley; MS-570

PO Box 1663

Los Alamos; NM 87545

Texas A\&M University

Dept. of Geosciences

Attn: $M$. Friedman, Dean

College Státion, TX 77843

US Department of Energy .

Office of Basic Energy Sciences

Attn: G. A. Kolstad

GPN Bldg. G-226

Washington, DC 20585

Shell Oil Company

Two Shell Plaza

Attn: E. Bingman

PO Box 2099

Houston, TX 77001

Mobil Research \&

Development Corporation

Dallas Research Laboratory

Attn: E. Martin

13777 Midway Rd.

Dallas, TX 75224

Amoco Production Company

Research Center

Aitn: T. Warren

PO Box 591

Tulsa, OK 74102

Stratabit

Attn: L. Matson

600 Kenrick, Suite A1

Houston, TX 77060

Dresser Industries

Security Division

Attn: J. Langford

PO Box 2467

Dallas, TX 75224
Union Oil Co. of California

Union Geothermal Division

Union Oil Center

Attn: S. Pye

461 S. Boylston

Los Angeles, CA 90017

US Department of Energy (3)

Geothermal Technologies Division

Forrestal Bldg., CE-324

Attn: R. Toms

J. Bresee

M. J. Reed

1000 Independence Ave., SW

Washington, DC 20585

Geothermal Resources International Inc.

Attn: J. Combs

1825 S. Grant, Suite 900

San Mateo, CA 94402

Livesay Consultants

Attn: B. J. Livesay

2616 Angell Ave. :

San Diego, CA 92122

US Department of Energy

Albuquerque Operations Office

Attn: G. P. Tennyson

PO Box 5400

Albuquerque, NM 87115

Geothermal Energy Research \&

Development Co., LTD.

Attn: Chuji Araki

Kyodo Bldg.

11-7, Kabuto-Cho, Nihonbashi

Chuo-Ku, Tokyo. 103, JAPAN

James Burns

32 Mahler Ct.

Appleton, WI 54915

University of Arkansas

Mechanical Engineering Department

Attn: $H$. Wolf

Fayetteville, AR 72701 


\section{DISTRIBUTION (continued):}

1000 W. F. Brinkman

1510 J. W. Nunziato

1511 A. M. Kraynik (10)

1511 L. A. Mondy

1520 W. Hermann, Actg.

1530 L. W. Davison

1540 W. C. Luth

1550 R. C. Maydew

1551 J. K. Cole

1552 C. W. Peterson

1553 S. McAlees, Jr.

1553 B. F. Blackwell (20)

1554 D. D. McBride

1555 W. R. Barton

1556 W. L. Oberkampf

1813 P. B. Rand

5214 M. E. Larsen

6200 V. L. Dugan

6241 L. E. Duda, Jr. (20)

6242 J. C. Dunn

6242 A. Ortega

6300 R. W. Lynch

6330 W. D. Weart

6422 D. A. Powers

7521 S. T. LeTourneau

7530 T. B. Lane

7531 D. R. Schafer

7533 F. H. Mathews

7535 D. C. Bickel

7537 N. R. Keltner

7537 K. B. Sobolik (10)

8024 P. W. Dean

3141 S. A. Landenberger (5)

3151 W. L. Garner (3) 